\title{
HEGYI ÁDÁM
}

egyetemi adjunktus

https://orcid.org/0000-0002-9575-5531

Szegedi Tudományegyetem Bölcsészet- és Társadalomtudományi Kar

Kulturális Örökség es Humán Információtudományi Tanszék

University of Szeged, Department of Cultural Heritage and Human Information Science

hegyiadamaalex@gmail.com

\section{EARLY MODERN DISPUTATIONS AND DISSERTATIONS IN AN INTERDISCIPLINARY AND EUROPEAN CONTEXT}

\author{
Meelis Friedenthal, Hanspeter Marti, Robert Seidel (ed.) \\ Brill, Boston-Leiden, 2021 (Intersections. Interdisciplinary studies \\ in early modern culture, 71.), XXV, 908 lap
}

A koraújkor az egyetemek időszaka. Ez tény, annak ellenére, hogy a történelemben ugyanekkor sok más jelentős esemény is történt. A középkori egyetemalapítások után a 16. században a reformáció, majd a 18. században a felvilágosodás az európai egyetemi struktúrában komoly változásokat hozott. A tudomány működésének alapvető kerete, vagyis a viták és ellenérvek mai rendszere ekkor alakult ki. A középkori diákszállásokon, illetve az egyetemi kurzusokon szóban gyakorolt disputák a kora újkorban váltak az egyetemi tanulmányok lezáróivá, illetve a doktori fokozat megszerzésének előfeltételévé. A 16. századtól kezdve terjedt el az a szokás, hogy a szóbeli viták szövegét nyomtatott formában közzé tegyék. Kezdetben ez csak a legfontosabb tézisek néhány pontban való összefoglalását jelentette, majd megjelentek azok a tézisfüzetek, amelyek már több oldalon keresztül fejtették ki a disputa tételeit. Ebből alakult ki aztán a 19-20. században a disszertáció mai formája, ma már a jelölt több száz oldalas tudományos dolgozatban mutatja be új eredményeit.

Az európai egyetemek életútja során nem mindegyik intézményben terjedt el a nyomtatott tézisfüzetek használata. Jelenlegi ismereteink szerint ezt alapvetően meghatározta a felekezeti hovatartozás, ugyanis a disputa sokkal népszerűbb volt a protestáns egyetemeken, mint a katolikus intézményekben. Itáliában, Spanyolországban és Portugáliában alig találunk kora újkori nyomtatott disszertációkat, és Franciaországban is

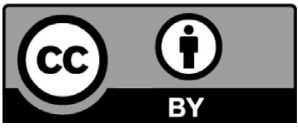

Beérkezett: 2021. 02. 15.

Közlésre elfogadva: 2021. 05. 15.

Copyright GERUNDIUM 
inkább csak a hugenotta egyetemeken adták ki a téziseket nyomtatásban. Német nyelvterületen viszont katolikus intézményekben is gyakori volt a disputáció.

Mivel a koraújkorban az egyetemek száma folyamatosan emelkedett, a 18. század végéig több százezer tézisfüzet jelent meg nyomtatásban. Ezek beazonosítása, katalogizálása és tudományos elemzése nem egyszerủ folyamat. Ráadásul formai szempontból sem egyszerü meghatározni, mit tekintünk tézisfüzetnek, disputációnak vagy disszertációnak. A szakirodalom tipologizálása szerint a legegyszerủbb egyetemi kiadványokról beszélnünk, amely egy összefoglaló megnevezése az egyetemi tanulmányokhoz, valamint az egyetem működéséhez kapcsolódóan megjelent nyomdatermékeknek. Ezek között találunk disszertációkat, disputációkat, téziseket, ünnepi beszédeket, egyetemi professzor felett tartott halotti prédikációkat, rektorválasztás vagy dékánválasztás alkalmából kiadott nyomtatványokat, jubileumot ünneplő füzeteket, meghívókat és elöadásjegyzékeket. Az egyetemi kiadványok rendszerint aprónyomtatványok voltak: az egylapos meghívótól egészen a néhány tíz oldalas disszertációig tart a terjedelmük.

Recenziónkban szereplő könyv nemcsak a nyomtatott disszertációkkal, hanem olyan disputákkal is foglalkozik, amelyeket nem egyetemeken vagy nem egyetemi tanulmányok során tartottak. Ez az elemzési szempont jogos, hiszen a koraújkorban több olyan föiskola, gimnázium is müködött, amelyek felsőfokú képzést nyújtottak, és rendszerint tartottak disputációkat. Katolikus intézményekben ráadásul a disputák gyakran nem a tanulmányokhoz, hanem jubileumokhoz, illetve az egyetem patrónusaihoz kapcsolódtak.

Valószínűleg a méretük és nagy számuk miatt a nyugat-európai kutatók az egyetemi kiadványok iránt kevésbé érdeklődnek. Szubjektív véleményem szerint jelenleg egyedül Hanspeter Marti tekinti szívügyének kutatásukat, mások inkább csak alkalomszerűen foglalkoznak velük. Éppen ezért hosszú idő fog még eltelni, mire kézikönyvi vagy monografikus feldolgozásuk el fog készülni, ezért is örvendetes tény, hogy 2021-ben a Brill kiadó egy kézikönyvpótló kötettel jelentkezett, amely a koraújkori európai disputációkat és disszertációkat mutatja be. A kötet szerkesztői között megtaláljuk a fentebb említett Hanspeter Martit, aki évtizedek óta egy svájci kisvárosban, Engiben vezet egy családi fenntartású kutatóintézetet. Az Arbeitsstelle für kulturwissenschaftliche Forschungen impozáns köteteket adott már közre, amelyek világviszonylatban is jelentős tudományos kiadóknál jelentek meg. Martin kívül egy észt és egy német szerkesztője van még a kötetnek, amely azt mutatja, hogy az egyetemek történetének kutatása igazán nemzetközi érdeklődésre tart számot. Meelis Friedenthal a tartui egyetem kutatója. Munkássága leginkább a kora újkori német disszertációkban található toleranciaértelmezésekkel koncentrál. Robert Seidel Frankfurt am Mainban a német irodalom professzoraként dolgozik, alapvetően a kora újkori latin irodalmat és egyetemtörténetet kutatja.

Összesen harminchárom szerző tanulmányát közlik a könyvben, akik között a német, a skandináv és a balti kutatók vannak többségben, de találunk köztük angol és magyar történészt is. Johanna Akujärvi a lundi egyetem oktatója, aki humanista görög szövegekkel és fordítástörténettel foglalkozik. Tommi Alho Finnországban az åboi 
egyetemen doktorált, eddig a koraújkori retorikát és neolatin irodalmat kutatta. A szerzők között művészettörténészt is találunk, ugyanis Sibylle Appuhn-Radtke a barokk ikonográfia kutatójaként a müncheni művészettörténeti intézetben dolgozik. Alberto Bardi bizantinológus, a középkori perzsa asztronómiának Bizáncra gyakorolt hatásával foglalkozik. Az orosz származású Daria Barow-Vassilevitch jelenleg a berlini városi könyvtárban a kéziratgyüjtemény munkatársa, kutatómunkája alapvetően a königsbergi egyetem történetével kapcsolatos. Innsbruckban dolgozik William M. Barton, ahol a Ludwig Boltzmann Intézet munkatársaként a neolatin irodalom kutatója. Barton közvetlen munkatársa Isabella Walser-Bürgler az egyetemi orációk kutatója. A duisburgesseni egyetem posztdoktori ösztöndíjasa Jan-Hendryk de Boer, aki kutatómunkája során a koraújkori értelmiséggel, valamint az egyetemek történetével kapcsolatban tett közzé publikációkat. Laurence Brockliss az oxfordi egyetem emeritus professzora, tudománytörténettel és az orvoslás történetével foglalkozik. Donald Felipe San Franciscoban filozófiaprofesszorként dolgozik, alapvetően filozófiatörténettel és a disputációk történetével kapcsolatos publikációi vannak. Szintén amerikai kutató Joseph S. Freedman, aki Alabamában él, és a humanista filozófia valamint a skolasztika szakértője. A kötet egyetlen magyar szerzője Förköli Gábor, aki Párizsban doktorált és jelenleg az ELTE-n tanársegéd. Reinhold F. Glei görög és római antik szerzők recepcióját kutatja a koraújkori Európában, jelenleg a bochumi egyetem klasszika-filológia professzora. Stephanie Hellekamps neveléstörténész, Münsterben a pedagógia professzora. A berlini Freie Universität klasszika-filológusa Bernd Roling, aki a neolatin irodalom mellett koraújkori tudománytörténettel is foglalkozik. Stockholmban a svéd koraújkori disszertációk és a politika kapcsolatából doktorált Andreas Hellerstedt. Szintén Svédországban szerezte meg doktori fokozatát Axel Hörstedt, aki a svéd gimnáziumokban gyakorolt disputációs kultúráról írta dolgozatát. A kötet további svéd szerzője Bo Lindberg, aki a göteborgi egyetemen emeritus professzor. Peter Sjökvist is svéd, az uppsalai egyetem latin professzora. A finn Tampere egyetem összehasonlító irodalomtörténeti intézetének professzora Sari Kivistö, aki a neolatin szatíra és a neolatin disputációk közötti összefüggéseket kutatja. A kötet további finn szerzője Tua Korhonen, aki a humanista görög irodalom svédországi és finn recepciójának szakértője. A Baltikumot képviseli Kaarina Rein, aki a tartui egyetem kora újkori orvosi disszertációinak történetét kutatja. Arvo Tering szintén észt, aki a Baltikum koraújkori peregrinusaival foglalkozik. A kötet másik észt szerzője Janika Päll, aki Tartuban a klasszika-filológia professzora. Annamaria Lesigang-Bruckmüller Bécsben élő kalsszika-filológus. Kutatásai az útleírásokban az egyetemekre vonatkozó részek elemzésével kapcsolatosak. A zürichi központi könyvtár régi nyomtatványok részlegének vezetője Urs B. Leu, aki a zürichi reformátorokról és humanistákról már több kötetet is közreadott. Francia művészettörténész Véronique Meyer, akinek munkássága az illusztrált tézisfüzetekkel kapcsolatos. Neveléstörténettel, az egyetemi oktatás történetével foglalkozik Hans-Ulrich Musolff, aki a münsteri egyetem munkatársa. A londoni King’s College-ben védte meg disszertációját Lucy Rachel Nicholas, akinek legfontosabb kutatási témái a kora újkori hitviták és a 
fordítástörténet. Pietro Daniel Omodeo professzor Velencében, és egy ERC kutatás vezetője, amelynek keretében a 17. századi Európa kozmológiájával foglalkoznak. Sabine Schlegelmilch és Ulrich Schlegelmilch tudománytörténészek, illetve orvostörténészek. Mindketten a koraújkori orvoslás történetéről írtak különböző könyveket. A könyv egyetlen németalföldi szerzője Raf Van Rooy nyelvész, aki a koraújkori görög nyelv történetét kutatja, de a kötetben nem Németalfölddel, hanem Wittenberggel foglalkozik.

A kötet valójában nem kézikönyv, de felépítésében hasonlít rá, mert összeállítói igyekeznek az európai disszertációk teljes történetét bemutatni, ezért minden olyan régiót érintenek, ahol a tézisfüzetek az egyetemi élet rendszeres szereplői voltak. Mivel a Mediterráneumban viszonylag csekély számú disszertáció jelent meg nyomtatásban, ezért a kötet nem foglalkozik Itália, Spanyolország és Portugália egyetemeivel, egyedül Sibylle Appuhn-Radtke tanulmánya tér ki néhány itáliai példára, valamint Alberto Bardi és Pietro Daniel Omodeo közös tanulmánya említ Paduával kapcsolatos összefüggéseket. A kötet szerkesztési elvében aránytalanságokat lehet felfedezni, mert Németalföld csak említés szintjén van jelen, viszont a Baltikum és Svédország egyetemeivel tíz publikáció is foglalkozik. Véleményem szerint a Rigai Akadémiai Gimnáziumhoz hasonlóan a nagyszombati egyetem is mérhető európai viszonylatban, ezért a kötetben igazán helye lett volna a nagyszombati intézménynek is.

Annak ellenére, hogy a könyv földrajzi alapon csoportosítja a tanulmányokat, mégis - egyfajta bevezetóként - három elemzés általánosságban foglalkozik a koraújkori diszszertációkkal és disputációkkal. Hanspeter Marti, Meelis Friedenthal és Robert Seidel historiográfiai áttekintése sorra veszi az európai egyetemek disszertációinak és disputációinak a történetét, és igyekszik a legfontosabb szakirodalmakat is bemutatni. Így például Magyarország esetében az $R M N Y$ kötetekre is utal. Donald Felipe publikációja valószínűleg azért került a bevezető részbe, mert a kora újkori disputációs útmutatásokkal és kézikönyvekkel foglalkozik. Sibylle Appuhn-Radtke a tézisfüzetek megjelenési formáit és funkcióit mutatja be, viszont leginkább csak a katolikus nyomtatványokat, ugyanis elemzésének központjában az illusztrált kiadványok szerepelnek. Ezek közül is leginkább Isten, Szűz Mária és a szentek ábrázolását elemzi, így érthető okokból protestáns nyomtatványok alig kerülnek a látókörébe.

A könyv második fejezete kicsit nagyot mond, ugyanis a címe szerint Nagy-Britanniával foglalkozik, de az itt szereplő három tanulmány csak Cambridge, Oxford és London egyetemeit érinti, a skót egyetemek említés szintjén sem kerülnek elő. Lucy R. Nicholas a reformáció egyik alapkérdését az angol disputációkon keresztül mutatja be: 1547 és 1555 között nagyszámban adtak közre az eucharisztiával foglalkozó füzeteket. Tommi Alho átfogó képet fest a 17. századi oxfordi disputációs gyakorlatról, és William M. Barton a természetfilozófia hatását rekonstruálja oxfordi és cambridge-i disszertációkban.

Szintén keveset tudunk meg a francia disputációs gyakorlatról is, de ezt Laurence Brockliss tanulmánya részletesen megindokolja, ugyanis ebből megtudjuk, hogy nem- 
csak a felekezeti sajátosságok magyarázzák meg azt, hogy a francia egyetemeken kevésbé volt népszerü a disszertációk kinyomtatása, hanem az is, hogy nagyon sok példány a századok alatt elkallódott, és a közgyüjteményekbe kevés került be közülük. Minden bizonnyal ezért foglalkozik Véronique Meyer XV. Lajos felesége, Marie Leczinska tiszteletére megjelent teológiai tézisekkel, hiszen ezek a füzetek inkább reprezentációs célt szolgáltak, semmint az egyetemi képzésre jellemző általános disputációs gyakorlatot.

Sokkal terjedelmesebb fejezet viszont Németország, Ausztria és Svájc disszertációival foglalkozó rész, és itt is felmerülnek kisebb földrajzi problémák, hiszen a koraújkorban anakronisztikus Németországról, Svájcról és Ausztriáról beszélni. Ráadásul itt kerül közlésre Förköli Gábor - egyébként igen alapos - tanulmánya is, amelyben David Pareus magyarországi kapcsolatait mutatja be. A szerkesztők valószínűleg nem akartak külön Kelet-Európával foglalkozó részt összeállítani, ezért került ide Förköli munkája, hiszen Pareus Heidelbergben tanított. Szintén nem egyértelmű, hogy Daria BarowVassilevitch tanulmányát miért ide sorolták, hiszen az a königsbergi egyetem oroszországi könyvtárakba került disszertációit mutatja be.

A német nyelvterület egyetemeivel foglalkozó fejezetben alapvetően kétfajta publikációt találunk: egy adott egyetem disszertációit elemző munkákat, illetve tematikus felépítésűeket. A német egyetemek közül így Bázelről, Marbugról, Jénáról, Innsbruckról, Wittenbergről, Lipcséről és Zürichról találunk egy-egy tanulmányt.

Ulrich Schlegelmilch 1583 és 1609 között a Bázelben tartott sebészeti témájú disputációk elemzésével bizonyítja, hogy Bázelben ekkor már az orvosi képzés része volt a sebészeti mütéttan. Marburgban Johann Jakob Waldschmidt müködése alatt több mint 100 nyomtatott disszertáció jelent meg. Sabine Schlegelmilch tanulmánya szerint ezekben a karteziánus filozófia hatását mutatható ki. 1794 és 1795 között Jénában három olyan orvosi disszertáció jelent meg, amelyek John Brown skót orvos terápiás módszereit ismertették. Arvo Tering véleménye szerint ez azért volt a korban jelentős előrelépés, mert az ópium orvosi használata ekkor még újdonságnak számított. 1669-ben a jezsuita rend alapított Insbruckban egyetemet. Az intézményben a felvilágosodás korszerűsége és a jezsuiták konzervativizmusa állandó harcban állt egymással. Isabella Walser-Bürgler a teológiai kar protokolluma alapján elemzi, hogy a 18. század során tartott disputációk hogyan viszonyultak ehhez a harchoz. Közismert, hogy Wittenbergben Melanchton a görög nyelv professzora volt, és a teológus hallgatók számára a Szentírás tanulmányozásához kötelezővé tette ennek a nyelvnek az oktatását. Raf Van Rooy fedezte fel azt, hogy 1702-ben Wittenbergben egy olyan nyelvészeti iskola jött létre, amely az ógörög nyelv nyelvjárásaival foglalkozott. Ezek szerint a szent nyelvek tanulmányozása Wittenbergben nem csak a 16-17. században volt kiemelkedő. Annamaria Lesigang-Bruckmüller szerint a disszertációk története szempontjából fontos figyelembe vennünk egy speciális műfajt, a programmát, ez ugyanis disputációs témafelhívásnak volt tekinthető. A lipcsei egyetemen Lesigang-Bruckmüller több ilyen programmát is talált, amelyeket a jogi karon az 1750-es években tettek közzé. Zürich- 
ben csak 1833-ban alapítottak egyetemet, de a koraújkorban a zürichi föiskolán is készültek nyomtatott disputációk. Urs B. Leu publikációja ezeket a füzeteket mutatja be.

A nem egy egyetemre fókuszáló tanulmányok közül Sari Kivistö azt mutatja be, hogy a 18. század elején a német nyelvterület disszertációs gyakorlatában hogyan alakult át a kereskedőkről és iparosokról alkotott vélemény: ekkor jelent meg a művelt cipész és kertész ideája. Joseph $S$. Freedman kutatásai szerint a dillingeni egyetemen Georg Stengel elnöklete alatt megvédett disszertációk azért érdekesek, mert a filozófiatörténet kevésbé ismeri Stengelnek a művészetekről és a természetről alkotott véleményét. Reinhold F. Glei tanulmánya arra hívja fel a figyelmet, hogy az egyetemeken a Korán recepciójával is foglalkoztak. Jan-Hendryk de Boer szerint Duisburgban a 17. század közepén nem egyhangúlag fogadták el a kartezianizmust, amely szerinte a disputációk paratextusaiból, argumentációiból és a jelenlévő közönség reakcióiból állapítható meg. Stephanie Hellekamps és Hans-Ulrich Musloff közös tanulmánya azzal foglalkozik, hogy Vesztfáliában 1648 után nemcsak az egyetemeken, hanem a latin iskolákban is rendszeres volt a disputáció: a diákok a nyelvtanulás részeként vettek részt disputációkon.

A svéd és a balti egyetemek disputációit bemutató részben az első tanulmányt Meelis Friedenthal írta. A 17. században Uppsalában, Tartuban és Turkuban a rámizmus a fénykorát élte, amelyet Friedenthal filozófiai témájú disszertációk elemzésével igazol. Bo Lindberg a disszertációk speciális paratextusával, a corollariával foglalkozik. Lindberg mintegy 200 olyan tézisfüzetet gyüjtött össze, amely corolláriákat is tartalmaz. Mivel ezek a legtöbb esetben a disszertáció témájától teljesen függetlenek voltak, ezért tipológiájuk és elemzésük nemcsak a Baltikumban, hanem európai viszonylatban is további kutatásokra ösztönöz. Peter Sjökvist is paratextus-elemzéssel kapcsolatos eredményeit tette közzé: az uppsalai disszertációk dedikációs gyakorlatát elemzi.

1626-ban az uppsalai egyetem alapítóokiratában rögzítették, hogy az intézményben latinul, görögül és héberül lehet disputálni. Tua Korhonen a görög nyelvü disszertációkat dolgozta fel publikációjában. Az ógörög jelentőségére hívja fel a figyelmet Janika Päll is, aki tanulmányában nemcsak a svéd egyetemek, hanem az akadémiai gimnáziumok görög nyelvü disputációs gyakorlatát is elemzi. Szintén nyelvészeti megközelítésű Johanna Akujärvi publikációja, amelyben ógörög és latin irodalom svéd és finn fordításait mutatja be. Az ókori kultúra hatásával foglalkozik Kaarina Rein munkája, amelyben a rigai akadémián Herodotos történetírói tevékenységéről készült disputációkat gyüjti össze.

Andreas Hellerstedt tanulmánya már nem az antikvitással, hanem a politológiával foglalkozik. A 18. század közepén az uppsalai egyetemen több olyan wolfiánus disszertáció is született, amely az államelméletet tárgyalta. Bernd Roling elemzése szintén politikai megközelítést alkalmaz: azt mutatja be, hogy XII. Károly svéd király uralkodása idején a svéd egyetemek hogyan vélekedtek a norvég nyelvről és irodalomról, vagyis a norvég nemzet önállóságáról. 
A könyv utolsó tanulmánya a svéd gimnáziumok rendszerét ismerteti. Axel Hörstedt arra hívja fel a figyelmet, hogy ezekben az iskolákban is találunk felsőfokú oktatásra jellemző ismérveket, amelyekre a legjobb példa a disputációk és disszertációk gyakorlata.

Összességében elmondhatjuk, hogy Meelis Friedenthal, Hanspeter Marti és Robert Seidel az egyetemtörténet és az egyetemi kiadványok története szempontjából egy olyan tanulmánykötetet állított össze, amely megkerülhetetlen lesz a kutatók számára. 